\title{
PENGGUNAAN TIGA JENIS KERANG SEBAGAI BIOFILTER PADA PEMELIHARAAN UDANG WINDU(Penaeus monodon) DALAM SKALA LABORATORIUM
}

\author{
Suharyanto", Muharijadi Atmomarsono") dan Achmad Sudradjat"*)
}

\begin{abstract}
ABSTRAK
Tujuan penelitian ini adalah untuk mengetahui pengaruh penggunaan tiga jenis kekerangan sebagai biofilter media pemeliharaan udang windu terhadap laju pertumbuhan dan sintasan udang windu.

Wadah percobaan adalah 12 bak kaca serat berukuran 1 x 1 x 0,4 m yang masingmasing ditebari dengan 100 ekor udang windu PL30. Rancangan yang digunakan adalah rancangan acak lengkap dengan lima perlakuan dan masing-masing tiga ulangan. Perlakuan tersebut adalah $\mathrm{M}_{1}$ : kerang hijau (Perna viridis) hidup, $\mathrm{M}_{2}$ tiram (Crassostrea iredalei) hidup, $\mathrm{M}_{3}$ : kerang bangko (Geloina coaxan) hidup, $\mathrm{K}$ : tanpa kerang, dengan frekuensi pergantian air sama dengan perlakuan $M_{1}, M_{2}, M_{3}$, dan $K_{2}$.

Hasil penelitian menunjukkan, bahwa penggunaan kekerangan dapat menurunkan plankton yang berbahaya dan bakteri patogen dalam media air. Selain itu penggunaan tiram dan kerang hijau ternyata dapat meningkatkan biomassa total, sintasan, laju pertumbuhan dan efisiensi pakan udang windu $(\mathrm{P}<0,05)$, sedangkan kerang bangko hanya dapat meningkatkan efisiensi pakan pada udang windu $(\mathrm{P}<0,05)$.
\end{abstract}

\section{ABSTRACT: The Use of Three Different Bivalves Species as Biofilter for Tiger Prawn (P. monodon) Rearing Media. By: Suharyanto, Muharijadi Atmomarsono and Achmad Sudradjat.}

The experiment was aimed at finding out the effect of using three different bivalves species as biofilter for tiger prawn rearing media on the growth and survival rate of tiger prawn.

Twelve fiberglass tanks of $1 \times 1 \times 0,4 \mathrm{~m}$ in size were use in this experiment. Each tank was stocked with 100 individues of tiger prawn post larvae. Five treatments were applied with three replicates each in designed completely randomized design. Bivalves used were green mussels (Perna viridis as $\mathrm{M}_{1}$ ), slipper oysters (Crassostrea iredalei as $\mathrm{M}_{2}$ ), rhizoporae clams (Geloina coaxan as $\mathrm{M}_{3}$ ), while the control $(\mathrm{K})$ was without bivalves.

The results showed that the use of bivalves could decrease the abundance of dangerous phytoplankton and pathogenic bacteria in the water media. Either green mussels or oysters could increase the total biomass production, survival rate, daily growth rate, and feed efficiency of the cultured tiger prawn $(P<0,05)$, while clams could only increase feed efficiency of the cultured tiger prawn $(\mathrm{P}<0,05)$ compared to control.

KEYWORDS: Biofilter, tiger prawn, bivalves, rearing media, survival rate, growth.

\footnotetext{
*) Peneliti pada Balai Penelitian Perikanan Pantai, Maros

*) Peneliti pada Pusat Penelitian dan Pengembangan Perikanan, Jakarta
} 


\section{PENDAHULUAN}

Dalam budidaya udang intensif banyak kendala yang dihadapi sehingga dapat mengakibatkan kegagalan dalam produksi. Salah satu kendala tersebut adalah pengelolaan kualitas air yang tidak sesuai dengan prosedur-prosedur teknik budidaya yang telah dianjurkan, sehingga berakibat pada menurunnya aspek lingkungan hidup udang itu sendiri. Padahal aspek lingkungan dalam suatu ekosistem akuakultur merupakan faktor pembatas bagi organisme akuatik (Schmittou, 1991). Lingkungan yang buruk dalam tambak udang bisa disebabkan oleh adanya makanan berlebih yang dapat menyebabkan pembusukan di dasar tambak. Pemberian pakan yang kurang tepat di samping dapat menurunkan kualitas air, juga dapat menyebabkan terjadinya blooming plankton (Cholik dan Poernomo 1987), yang pada gilirannya akan berakibat pada penurunan daya dukung lahan seperti adanya kompetisi dalam hal penggunaan oksigen. Apabila hal ini tidak diantisipasi secara dini, maka kualitas air tambak akan menurun karena adanya plankton yang mati dan mengendap ke dasar tambak yang pada akhirnya akan mengganggu kehidupan udang yang dipelihara.

Untuk mengatasi masalah penurunan kualitas air perlu dilakukan perbaikan air, baik secara fisik, kimiawi maupun biologi. Pergantian air secara fisik dapat langsung dilaksanakan di tambak, tetapi hanya dapat dilakukan pada saat air pasang saja, sedangkan secara kimiawi sudah dilakukan oleh peneliti terdahulu antara lain dengan pergantian ion (Spotte 1979) dan penambahan senyawa silikat (Dharmadi dan Ahmad, 1988). Namun demikian, secara biologi belum banyak dilaksanakan, misalnya dengan menggunakan hewan lain untuk memperbaiki kualitas air. Salah satu di antaranya adalah penggunaan tiram (Crassostrea iredalei). Tiram tersebut dapat digunakan sebagai biofilter untuk memperbaiki kualitas air, sebab tiram sangat toleran terhadap kondisi perairan yang buruk dan mengandung polutan, serta sangat cepat mengakumulasi logam berat (Coeroli et al., 1984). Penggunaan kerang bulu (Scaparca inaequivalvis) dan rumput laut (Gracilaria sp.) sebagai biofilter telah dicoba sebagai biofilter dalam budidaya udang intensif di Malaysia (Enander and Hasselstrom 1994).

Untuk mengantisipasi hal tersebut maka perlu dilakukan penelitian mengenai penggunaan beberapa jenis kekerangan sebagai biofilter dalam budidaya udang.

\section{BAHAN DAN METODE}

Percobaan dilakukan di Laboratorium Balai Penelitian Perikanan Pantai Maros dari bulan Oktober-Desember 1994 (8 minggu). Sebagai wadah percobaan adalah bak kaca serat berukuran $1 \times 1 \times 0,4 \mathrm{~m}$, yang dilengkapi dengan 4 kaki pada keempat sudutnya setinggi $0,25 \mathrm{~m}$ dari permukaan tanah. Hal ini dimaksudkan untuk mempermudah melakukan pembuangan air sebelum dilakukan penggantian air baru. Media pemeliharaan adalah air laut yang dipertahankan salinitasnya (25-30 ppt) sebanyak 200 liter.

Ke dalam setiap bak percobaan, dimasukkan kerang hidup sebagai biofilter dengan jumlah setara daging 125 gram (ditentukan berdasarkan percobaan pendahuluan). Perlakuan yang digunakan adalah kerang hijau (Perna viridis), tiram (Crassostrea iredalei), dan kerang bangko (Geloina coaxan) berturut turut sebagai M1, M2, dan M3; sedangkan K adalah bak tanpa kerang. Ke dalam setiap bak tersebut juga dimasukkan tokolan udang windu (PL 30) sebanyak 25 ekor (100 ekor/ $\mathrm{m}^{3}$ ) sebagai hewan uji. Frekuensi pergantian air adalah 2 kali per minggu dengan jumlah penggantian air $20 \%$. Aerasi dilakukan secara rutin menggunakan blower.

Masing-masing perlakuan memiliki 3 ulangan, pengambilan percontoh dilakukan 2 minggu sekali selama 8 minggu. Peubah yang dipantau adalah biomassa total, sintasan, laju pertumbuhan harian, dan efisiensi pakan. Data yang diperoleh dianalisis menggunakan prosedur "General Linear Model" dalam program SAS (Statistical Analysis System), sedangkan kualitas air yang dipantau setiap dua minggu adalah $\mathrm{DO}$, suhu air, $\mathrm{pH}$, salinitas, BOT, $\mathrm{NO}_{2}-\mathrm{N}, \mathrm{NO}_{3}-\mathrm{N}, \mathrm{NH}_{4}-\mathrm{N}, \mathrm{PQ} \cdot \mathrm{P}$ dan kandungan plankton. Pengambilan sampel kualitas air dilakukan pada jam 08.00 
dan data kualitas air ditabulasikan dan dianalisis secara deskriptif.

\section{HASIL DAN PEMBAHASAN}

Berdasarkan hasil pengamatan yang dilakukan setiap 2 minggu selama 8 minggu, didapatkan rata-rata biomassa total, kelangsungan hidup, laju pertumbuhan harian, dan efisiensi pakan seperti yang disajikan pada Tabel 1.

Tabel 1 di atas memperlihatkan, bahwa secara umum penggunaan kekerangan dalam budidaya udang windu dapat meningkatkan biomassa total, sintasan, laju pertumbuhan harian, dan efisiensi pakan bagi udang windu yang dipelihara.

Penggunaan tiram atau kerang hijau dalam pemeliharaan udang windu ternyata memberikan pertumbuhan biomassa total dan laju pertumbuhan harian yang lebih cepat $(\mathrm{P}<0,05)$ daripada penggunaan kerang bangko ataupun tanpa kerang (kontrol 1 dan 2). Penggunaan kerang bangko memberikan pertumbuhan biomassa total yang berbeda tidak nyata $(\mathrm{P}>0,05)$ dengan kontrol sedangkan laju pertumbuhan harian udang windu pada penggunaan kerang bangko berbeda tidak nyata $(\mathrm{P}>0,05)$ dengan kontrol (tanpa kerang).

Penggunaan tiram ternyata juga dapat meningkatkan sintasan udang windu yang dipelihara. Kelangsungan hidupnya $(86,0 \%)$ adalah lebih tinggi $(P<0,05)$ daripada sintasan udang windu dengan penggunaan kerang bangko dan tanpa kerang, sedangkan penggunaan kerang hijau menghasilkan sintasan udang windu yang berbeda tidak nyata $(P>0,05)$ dengan penggunaan tiram atau kerang bangko, namun berbeda nyata $(\mathrm{P}<0,05)$ dengan perlakuan tanpa kerang.

Tabel 1. Produksi total biomassa, sintasan, laju pertumbuhan harian, dan efisiensi pakan udang windu yang dipelihara dengan kekerangan yang berbeda spesies sebagai biofilter media pemeliharaan udang windu setelah 8 minggu percobaan pada skala laboratorium.

Table 1. Total biomass production, survival rate, daily growth rate, and feed efficiency of tiger prawn reared for 8 weeks in laboratory scale using different bivalves species as biofilter.

\begin{tabular}{|c|c|c|c|c|}
\hline $\begin{array}{l}\text { Perlakuan } \\
\text { Treatment }\end{array}$ & $\begin{array}{c}\text { Total } \\
\text { biomassa } \\
\text { Total } \\
\text { biomass } \\
\text { (g) }\end{array}$ & $\begin{array}{l}\text { Sintasan } \\
\text { Survival } \\
\text { rate } \\
(\%)\end{array}$ & $\begin{array}{l}\text { Pertumbuhan } \\
\text { harian } \\
\text { Daily growth } \\
\text { rate } \\
(\%)\end{array}$ & $\begin{array}{c}\text { Efisiensi } \\
\text { pakan } \\
\text { Feed } \\
\text { efficiency } \\
(\%)\end{array}$ \\
\hline $\begin{array}{l}\text { Kerang hijau } \\
\text { Green mussels }\end{array}$ & $158,13^{a}$ & $81,7^{\text {ab }}$ & $5,87^{\text {a }}$ & $39,4^{\text {a }}$ \\
\hline $\begin{array}{l}\text { Tiram } \\
\text { Slipper oysters }\end{array}$ & $164,23^{n}$ & $86,0^{a}$ & $5,92^{\text {a }}$ & $38,4^{\text {a }}$ \\
\hline $\begin{array}{l}\text { Kerang bangko } \\
\text { Rhizophora clams }\end{array}$ & $104,13^{b}$ & $71,0^{b c}$ & $5,20^{b}$ & $37,3^{\text {a }}$ \\
\hline $\begin{array}{l}\text { Kontrol } \\
\text { Control }\end{array}$ & $89,43^{\text {b }}$ & $67,7^{c}$ & $4,91^{b c}$ & $28,4^{b}$ \\
\hline
\end{tabular}

Catatan (Notes):

- Nilai yang diikuti oleh huruf yang sama dalam kolom yang sama menunjukkan berbeda tidak nyata(Values followed by similar superscripts in the same column are not significantly different) $(p>0,05)$.

- Kontrol tanpa kekerangan, frekuensi penggantian air sama dengan perlakuan lain (Control with out bivalves, frequency of water exchange is equal to other treatments). 
Penggunaan kekerangan (tiram, kerang hijau, ataupun kerang bangko) ternyata juga dapat meningkatkan efisiensi pemanfaatan pakan yang diberikan. Ketiganya berbeda nyata $(\mathrm{P}<0,05)$ dengan perlakuan tanpa kerang. Hal ini dimungkinkan karena kerang tersebut memberikan aroma tertentu dalam media pemeliharaan akibat kandungan asam lemak tak jenuh (asam lemak linolenat). Dalam kondisi demikian tidak menutup kemungkinan bahwa kerang tersebut juga dapat dimakan udang secara langsung. Pada waktu masih hidup, kerang memang relatif susah untuk dimakan udang, karena cangkangnya jarang terbuka lebar. Namun pada waktu mati, cangkang kerang akan terbuka lebar dan udang dapat dengan leluasa memakannya. Selama percobaan didapatkan bahwa kematian kerang hijau lebih sering terjadi daripada kematian tiram dan kerang bangko. $\mathrm{Hal}$ ini karena dalam penyerapan makanannya, kerang hijau membuka cangkang lebih lebar daripada tiram dan kerang bangko, sedangkan kerang bangko membuka cangkangnya hanya pada kondisi gelap (tanpa cahaya).

Dalam hal kandungan logam berat (Ismawati, 1995), menyatakan bahwa tiram mempunyai kemampuan mengakumulasi $\mathrm{Pb}$ dan $\mathrm{Cu}$ paling tinggi, yaitu masing-masing adalah $1185 \%$ dan $473 \%$ dari kandungan awalnya (0,013 dan $0,238 \mathrm{ppm})$, sedangkan kerang bangko mempunyai kemampuan mengakumulasi $\mathrm{Zn}$ yang tertinggi di antara tiga jenis kekerangan yang dicobakan, yaitu $431 \%$ dari kandungan awalnya $(0,515 \mathrm{ppm})$. Penggunaan kekerangan ternyata secara tidak langsung telah mengurangi akumulasi logam berat pada udang yang dipelihara. Lebih jauh Ismawati (1995) menyatakan bahwa kandungan logam berat pada udang yang dipelihara bersama kekerangan relatif lebih rendah dibandingkan dengan yang didapatkan pada udang tanpa moluska. Sedangkan dalam hal kandungan jumlah bakteri, Muliani et al., (1995) menyatakan bahwa penggunaan kekerangan (kerang hijau, tiram dan kerang bangko) dapat menurunkan jumlah bakteri yang dapat tumbuh dalam media TCBSA (media selektif untuk bakteri patogen, terutama vibrio spp.).
Ditinjau dari kemampuan hidup dan manfaat bagi udang windu yang dipelihara, serta kemudahan untuk diperoleh, maka dari hasil penelitian ini dapat disimpulkan bahwa penggunaan tiram adalah lebih baik daripada kerang hijau dan kerang bangko. Hal ini karena selain kerang hijau relatif sulit didapat di Sulawesi Selatan juga kurang tahan terhadap salinitas rendah (di bawah 10 ppt). Menurut Suharyanto et al. (1994), di Sulawesi Selatan jumlah benih kerang hijau yang ditemukan hanya berkisar 2-25 benih per kolektor dan hanya dijumpai pada salinitas antara $31.38 \mathrm{ppt}$. Jumlah ini relatif sedikit bila dibandingkan di Teluk Jakarta (Kastoro, 1992). Selain itu pada bak penampungan, kerang hijau mudah mati pada musim pemijahan, di mana air pemeliharaan menjadi berbusa dan keruh. Sedangkan kerang bangko yang relatif mudah didapatkan terutama pada perairan yang banyak ditumbuhi pohon nipah, terlihat hanya berperan dalam meningkatkan efisiensi pakan bagi udang yang dipelihara secara polikultur, sedangkan dalam hal pertumbuhan dan kelangsungan hidup udang, penggunaan kerang bangko sebagai biofilter belum menunjukkan perbedaan yang nyata dengan kontrol. Hal ini karena habitat asli kerang bangko adalah di dalam tanah gambut, sedangkan dalam penelitian ini tidak digunakan substrat tanah.

Pengamatan kualitas air selama penelitian yang mendukung kehidupan udang dan kerang (Tabel 2), menunjukkan kisaran oksigen terlarut pada masing-masing perlakuan, masih dalam kisaran yang disarankan bagi kehidupan udang. Menurut Boyd (1979), pada kadar oksigen terlarut 5 ppm ikan akan tumbuh normal dan apabila kadar oksigen terlarut dapat mencapai $7 \mathrm{ppm}$, maka ikan akan tumbuh dengan cepat dan berkem. bang biak dengan baik.

Demikian juga suhu air, $\mathrm{pH}$, salinitas, BOT, $\mathrm{NO}_{3}-\mathrm{N}, \mathrm{NH}-\mathrm{N}$, dan $\mathrm{P}_{4} \mathrm{O}-\mathrm{P}$ masingmasing masih dalam rentang yang layak bagi kehidupan udang dan organisme lainnya. Hanya $\mathrm{NO}_{2}-\mathrm{N}$ yang didapatkan cukup tinggi, terutama pada perlakuan $\mathbf{M}_{1}, \mathbf{M}_{2}$, dan $\mathbf{M}_{3}$ hasil yang didapatkan lebih tinggi daripada $\mathrm{K}_{1}$ dan $\mathrm{K}_{2}$. Hasil nitrit yang tinggi ini diduga 
berasal dari pakan yang berlebih dan berasal dari hasil metabolisme udang dan kerang. Sedangkan $K_{1}$ dan $K$ hanya berasal dari metabolisme udang saja dan pakan yang berlebih. Menurut Schmittou (1991), nitrit merupakan limbah metabolik dari suatu organisme. Dikatakan selanjutnya bahwa nitrit $\left(\mathrm{NO}_{2}\right)$ dalam ekosistem akuakultur adalah produk kegiatan biologi yang berhubungan dengan penguraian bahan organik komponen-komponen protein. Nitrit dihasilkan dari $\mathrm{NH}_{4}-\mathrm{N}$ melalui proses oksidasi secara primer oleh bakteri nitrosomonas dan dari $\mathrm{NO}_{3}-\mathrm{N}$ melalui suatu proses reduksi oleh mikroorganisme anaerobik. Jadi, dilihat dari hasil nitrit yang didapatkan sebetulnya sudah cukup membahayakan. Schmittou (1991) mengatakan, bahwa konsentrasi nitrit $0,1 \mathrm{ppm}$ dapat menyebabkan stres pada ikan dan dapat menyebabkan kematian bila konsentrasi nitrit mencapai $1,0 \mathrm{ppm}$. Tingkat konsentrasi nitrit paling tinggi dalam ekosistem akuakultur bila tingkat oksigen terlarut rendah, sedangkan hasil pemantauan oksigen terlarut pada masing-masing perlakuan masih dalam kisaran yang layak (4,4-7,0 ppm). Hal ini karena pada masing. masing perlakuan dilakukan aerasi secara terus menerus, sedangkan penggantian air $20 \%$ (1-4 kali/minggu), dan penyiponan setiap pagi hari, diharapkan juga dapat mengurangi toksisitas nitrit. Kemudian Schmittou (1991)

Tabel 2. Kisaran nilai parameter kualitas air selama 8 minggu percobaan pemeliharaan udang windu pada tangki kaca serat $1 \times 1 \mathrm{~m}$ dengan menggunakan berbagai spesies bivalvia sebagai biofilter untuk media pemeliharaan udang windu.

Table 2. Range of values of water quality parameters during eight weeks of experiment of tiger prawn rearing in $1 x 1 \mathrm{~m}$ fiber glass tank using different bivalves species as biofilter for tiger prawn culture media.

\begin{tabular}{|c|c|c|c|c|c|c|}
\hline \multicolumn{2}{|c|}{ Parameters } & $\mathbf{M}_{1}$ & $\mathbf{M}_{2}$ & $\mathbf{M}_{3}$ & $\mathbf{K}_{1}$ & $\mathbf{K}_{2}$ \\
\hline \multicolumn{2}{|c|}{ Oksigen terlarut } & $4,4-6,6$ & $4,6 \cdot 6,8$ & $5,3-6,9$ & $5,5-6,4$ & $5,9 \cdot 7,09$ \\
\hline $\begin{array}{l}\text { Suhu } \\
\text { (Temp.) }\end{array}$ & $\left({ }^{\circ} \mathrm{C}\right)$ & $25,5-26,4$ & $25,4-26,4$ & $25,4-26,4$ & $25,5-26,0$ & $25,4-26,3$ \\
\hline pH & & $7,3-8,0$ & $\mathbf{7 , 5 - 8 , 0}$ & $7,5-8,0$ & $7,8-8,0$ & $7,8-8,0$ \\
\hline $\begin{array}{l}\text { Salinitas } \\
\text { (Salinity) }\end{array}$ & (ppt) & $26,0-29,0$ & $26,0-29,0$ & $26,0-29,0$ & $26,0-29,6$ & $26,0-29,0$ \\
\hline \multicolumn{7}{|c|}{$\begin{array}{l}\text { Bahan organik } \\
\text { (Organic matter) }\end{array}$} \\
\hline TOM & (ppm) & $5,52-7,22$ & $5,60-7,57$ & $5,31-6,73$ & $5,56-6,57$ & $5,43-6,21$ \\
\hline $\mathrm{NO}_{2} \cdot \mathrm{N}$ & (ppm) & $0,5101-1,3628$ & $0,8817 \cdot 1,0873$ & $0,9477-1,0571$ & $0,2930-0,4453$ & $0,4464-1,1874$ \\
\hline $\mathrm{NO}_{3}-\mathrm{N}$ & (ppm) & $0,0000-0,0040$ & $0,0000-0,0403$ & $0,0000-0,0406$ & $0,0000-0,0040$ & $0,0000-0,0406$ \\
\hline $\mathrm{NH}_{4}-\mathrm{N}$ & (ppm) & $0,0669-0,5879$ & $0,0909-0,2433$ & $0,1223-0,2685$ & $0,0813-0,2911$ & $0,0648-0,3714$ \\
\hline $\mathrm{PO}_{4}-\mathrm{P}$ & (ppm) & $0,0038-0,0118$ & $0.0109-0.0114$ & $0,0112-0,0113$ & $0,0073-0,0109$ & $0,0114-0,0118$ \\
\hline
\end{tabular}

Keterangan (Notes):

$M_{1}$ : Kerang hijau sebagai biofilter, dengan 100 ind. udang windu/ $\mathrm{m}^{2}$ (Green mussels as biofilter, cultured with 100 ind. of tiger prawn $/ \mathrm{m}^{3}$ ).

$\mathrm{M}_{2}$ : Tiram sebagai biofilter dengan 100 ind. udang windu/ $\mathrm{m}^{2}$ (Oysters as biofilter, cultured with 100 ind. of tiger prawn $/ \mathrm{m}^{2}$ ).

$\mathrm{M}_{3}$ : Kepah Rhizophora sebagai biofilter, dengan 100 ind. udang windu/m² (Rhizopora clams as biofilter, cultured with 100 ind. of tiger prawn $\left./ \mathrm{m}^{2}\right)$.

$\mathrm{K}: 100$ ind udang windu/ $\mathrm{m}^{2}$ tanpa kekerangan (100 ind. of tiger prawn $/ \mathrm{m}^{2}$ without bivalves). 
Tabel 3. Komposisi dan kelimpahan plankton (ind/l) yang ditemukan selama delapan minggu percobaan dengan menggunakan berbagai kekerangan sebagai biofilter pada media budidaya udang windu.

Table 3. Composition and abundance of plankton (ind./l) found during eight weeks of experiment using different bivalves species as biofilter for tiger prawn culture media.

\begin{tabular}{|c|c|c|c|c|c|}
\hline $\begin{array}{l}\text { Genus plankton } \\
\text { Plankton genera }\end{array}$ & $\mathbf{M}_{\mathbf{l}}$ & $\mathbf{M}_{2}$ & $\mathbf{M}_{\mathbf{3}}$ & $\mathbf{K}_{1}$ & $\mathbf{K}_{\mathbf{2}}$ \\
\hline $\begin{array}{l}\text { Zooplankton } \\
\text { Brachionus } \\
\text { Globigerina } \\
\text { Tintinopsis }\end{array}$ & . & $\begin{array}{l}. \\
10 \\
10\end{array}$ & $\begin{array}{l}10 \\
10 \\
10\end{array}$ & $\begin{array}{r}10 \\
10\end{array}$ & $\begin{array}{r}10 \\
. \\
.\end{array}$ \\
\hline $\begin{array}{l}\text { Phytoplankton } \\
\text { Amphora } \\
\text { Ceratium } \\
\text { Chaetoceros } \\
\text { Coscinodiscus } \\
\text { Melosira } \\
\text { Microsystis } \\
\text { Nannochloropsis } \\
\text { Nitzschia } \\
\text { Oscillatoria } \\
\text { Peridinium } \\
\text { Tetraselmis }\end{array}$ & $\begin{array}{r}1000 \\
. \\
20 \\
10 \\
950 \\
10 \\
- \\
50 \\
15 \\
1798 \\
30\end{array}$ & $\begin{array}{r}60 \\
- \\
10 \\
. \\
5 \\
40 \\
15 \\
2790 \\
.\end{array}$ & $\begin{array}{r}200 \\
10 \\
. \\
. \\
. \\
. \\
20 \\
15 \\
980 \\
.\end{array}$ & $\begin{array}{r}2960 \\
. \\
10 \\
15 \\
. \\
2400 \\
. \\
2000 \\
3090 \\
.\end{array}$ & $\begin{array}{r}3350 \\
- \\
40 \\
10 \\
20 \\
. \\
. \\
- \\
20 \\
4130 \\
.\end{array}$ \\
\hline $\begin{array}{l}\text { Protozoa } \\
\text { Ciliata }\end{array}$ & 1000 & 10 & 15 & . & - \\
\hline
\end{tabular}

Keterangan (Notes) :

$M_{1}$ : Kerang hijau sebagai biofilter, dengan 100 ind. udang windu/ $\mathbf{m}^{2}$ (Green mussels as biofilter, cultured with 100 ind. of tiger prawn $/ \mathrm{m}^{2}$ )

$\mathrm{M}_{2}$ : Tiram sebagai biofilter dengan 100 ind. udang windu/ $\mathrm{m}^{2}$ (Oysters as biofilter, cultured with 100 ind. of tiger prawn $/ \mathrm{m}^{2}$ ).

$\mathrm{M}_{3}$ : Kerang bangko sebagai biofilter, dengan 100 ind. udang windu/ $\mathrm{m}^{2}$ (Rhizopora clams as biofilter,

cultured with 100 ind. of tiger prawn $\left./ \mathrm{m}^{2}\right)$.

$\mathrm{K}$ : 100 ind udang windu/ $\mathrm{m}^{2}$ tanpa kekerangan (100 ind. of tiger prawn $/ \mathrm{m}^{2}$ without bivalves).

mengatakan, bahwa toksisitas nitrit dalam ekosistem akuakultur dapat dicegah dengan jalan antara lain: 1. Membatasi laju pemberian pakan, 2. Secara mekanik mengaerasi/ mencampur air selama periode oksigen terlarut rendah, 3. Menambahkan atau mengalirkan air bermutu tinggi ke dalam ekosistem.

Hasil pengamatan kualitas plankton selama penelitian disajikan pada Tabel 3 . Jenis plankton yang paling dominan adalah
Peridinium dan ditemukan pada setiap perlakuan. Jenis plankton ini termasuk kelas Dinoflagellata. Sedangkan Dinoflagellata mampu menghasilkan bermacam zat racun yang dilepaskan ke dalam air laut. Bila Dinoflagellata sangat melimpah (2-8 juta sel/liter), zat racun yang dilepaskan ini akan dapat mempengaruhi organisme lainnya di lautan dan dapat menyebabkan kematian massal (Nybaken. 1982). Namun demikian dari hasil yang diperoleh pada masing. 
masing perlakuan jumlah plankton masih dalam kisaran yang wajar dan belum membahayakan kehidupan udang. Terlihat pada Tabel 3, bahwa penggunaan kekerangan baik kerang hijau maupun kerang bangko ternyata mampu menurunkan kelimpahan fitoplankton Peridinium (Dinoflagellata) dan Oscillatoria (Cyanophyceae) yang dikenal sebagai penghasil racun.

Selain Peridinium yang paling dominan, juga ditemukan jenis plankton Amphora spp. yang mendominasi pada setiap perlakuan. Peridinium merupakan jenis fitoflagela yang baik sedangkan Amphora termasuk Bacillariophyceae yang sangat bermanfaat sebagai makanan moluska (Imai, 1971), sedangkan jenis plankton lain dalam Tabel 3, termasuk ke dalam jenis plankton yang diperlukan oleh kekerangan sebagai makanan, kecuali yang termasuk protozoa. Jenis-jenis protozoa terdapat hanya pada perlakuan $\mathrm{M}_{1}, \mathrm{M}_{2}$, dan $\mathrm{M}_{3}$, sedangkan pada $\mathrm{K}$ tidak dijumpai. Hal ini diduga Ciliata tersebut berasal dari kekerangan. Namun demikian jumlahnya masih belum membahayakan bagi kehidupan udang .

\section{KESIMPULAN}

1. Penggunaan kerang sebagai biofilter dalam pemeliharaan udang secara intensif berfungsi baik dalam penyerapan plankton.

2. Penggunaan tiram atau kerang hijau yang dipelihara bersama dengan udang windu, ternyata dapat meningkatkan sintasan dan pertumbuhan udang windu pada skala laboratorium. Tetapi jika dilihat total biomassa, sintasan dan pertumbuhan harian, penggunaan tiram sedikit lebih baik jika dibandingkan penggunaan kerang hijau dan kerang bangko.

\section{UCAPAN TERIMA KASIH}

Diucapkan terima kasih kepada Ir. A. Parenrengi dan Rifka Pasande BSc. atas bantuan menganalisis plankton. Ucapan terima kasih juga disampaikan kepada Reni Yulianingsih, Nurbaya dan Nurjanah masingmasing sebagai analis Balitkanta, serta Abdul
Hakim teknisi Balitkanta, yang telah banyak membantu selama penelitian ini berlangsung.

\section{DAFTAR PUSTAKA}

Boyd, C.E. 1979. Water quality in warmwater ponds. Auburn University. 354p.

Cholik, F. dan A. Poernomo. 1989. Pengelolaan mutu air tambak untuk budidaya udang intensif. Dalam; Kumpulan makalah seminar teknik budidaya udang intensif. PT. Kalorin Kreasi Bahang. Medan. Jakarta. Surabaya. Ujung Pandang. Hal. 1-45.

Coeroli, M., D.D. Gaillande., J.P. Landert and Aquacop. 1984. Recent innovation in cultivation of mollusc in French Polynesia. Aquaculture, 4(1): 45-67.

Dharmadi dan T. Ahmad. 1988. Pengaruh penggunaan senyawa silikat dalam budidaya udang windu secara intensif. J. Penel. Budidaya Pantai. 4(1): 41-47.

Enander, M., and M. Hasselstrom. 1994. An experimental wastewater treatment system for a shrimp farm. Aquaculture. In Infofish International. No. 4/1994:56-61.

Imai, T. 1971. Aquaculture in shallow seas. Progress in Shallow Seas Culture. Oxford \& IBH Publishing Co., New Delhi, Bombay, Calcuta. 615 p.

Ismawati, S. 1995. Pemantauan kandungan logam berat pada budidaya udang intensif. Laporan penelitian. Balai Penelitian Perikanan Pantai, Maros. $10 \mathrm{Hal}$.

Kastoro, W.W. 1992. Beberapa aspek biologi dan ekologi jenis-jenis moluska laut komersial yang diperlukan untuk menunjang usaha budidayanya. Dalam Mansur, H., Rachmansyah, A. Mustafa, A.M. Pirzan (Eds.). Prosiding Temu Karya Ilmiah Sumber Daya Kekerangan Sulawesi Selatan dan Tenggara. Watampone. hal. 68-79

Muliani, M. Atmomarsono dan M.I. Madeali. 1995. Pengamatan bakteri pada budidaya udang intensif. Laporan Penelitian. Balai Penelitian Perikanan Pantai, Maros. $8 \mathrm{Hal}$.

Nybaken, J.W. 1982. Marine biology: An Ecological Approach. Harper \& Row. Publishers, New York. 459 p.

Schmittou, H.R. 1991. Budidaya keramba: Suatu metode produksi ikan di Indonesia. FRDP. Puslitbang Perikanan, Jakarta. Indonesia. 126 Hal. 
Suharyanto; Atmomarsono, M. dan Sudradjat, A.

Spotte, S. 1979. Fish and invertebrate culture.

Water Management in Clossed System. Sec. Ed. John Willey and Son. New York. p. 179.

Suharyanto, B. Pantjara, A. Sudradjat dan A.M Tangko. 1994. Fluktuasi penempelan benih kerang hijau, Perna viridis di Perairan Binangasangkara, Kabupaten Pangkep, Sulawesi Selatan. Warta Balitdita. Balai Penelitian Perikanan Budidaya Pantai, Maros. 6(1): 24. 25. 